\title{
The importance of livestock grazing at woodland-grassland interface in the conservation of rich oakwood plant communities in temperate Europe
}

\author{
Paweł Wolański ${ }^{1}$ - Andrzej Bobiec ${ }^{2}$ (D) - Bernadetta Ortyl ${ }^{2} \cdot$ Iwona Makuch-Pietraś $^{2}$. \\ Paweł Czarnota $^{3}$. Jan Ziobro ${ }^{4} \cdot$ Mykola Korol $^{5}$. Serhii Havryliuk ${ }^{5}$. Jakub Paderewski ${ }^{6}$. \\ Keith Kirby ${ }^{7}$
}

Received: 7 September 2020 / Revised: 30 December 2020 / Accepted: 10 January 2021 /

Published online: 27 January 2021

(C) The Author(s) 2021

\begin{abstract}
Traditional husbandry fostered rich semi-open oakwood communities composed of forest and non-forest species. In the eastern Carpathian region, silvo-pastoralism was commonplace by the mid-1900s. This study aimed to determine the state of the preservation of the ecotonal character of grassland-woodland interfaces in formerly pastured cultural landscapes of SE-Polish Carpathian foothills and W-Ukrainian Ciscarpathia in the context of land-use change. In the first region, despite the long-lasting history of forest grazing amongst mainly arable land, the post-WWII collapse of husbandry and the imposed ban on forest grazing, has led to swift development of dense undergrowth and establishment of impermeable ecological woodland-open habitat barrier. As a result, former silvo-pastoral oakwoods developed the features of the Tilio-Carpinentum forest community although some forest species have not yet moved in due to their poor dispersibility. The much younger oakwoods in the Ukrainian study region are remnants of the sparsely treed grasslands, some of which had been ploughed in the mid 20th century. Their semi-open canopy structure, maintained through repetitive grass burning, contributes to the communities ecotonal character, but without regular livestock-led plant "spill-over" from the grassland, the oakwoods remain species-poor. The restoration of species-rich semi-open oak woods requires "unsealing" the forest-grassland interface, reducing the degree of canopy closure, and opening that zone up to extensive grazing - an important seed dispersal vector.
\end{abstract}

Keywords Conservation grazing $\cdot$ Ecotonal plant communities $\cdot$ Grassland-woodland ecological barrier $\cdot$ Land-use change $\cdot$ Semi-open oakwoods $\cdot$ Wooded traditional landscape

Communicated by Daniel Sanchez Mata.

Supplementary Information The online version of this article (https://doi.org/10.1007/s10531-02102115-9) contains supplementary material, which is available to authorized users.

Andrzej Bobiec

a_bobiec@ur.edu.pl

Extended author information available on the last page of the article 


\section{Introduction}

Thermophilous oak woodland Potentillo albae-Quercetum was common throughout Central Europe until the mid-1900s, but has been in sharp decline since, leading to it being recognized as a habitat 'of the Community interest' (habitat code 91I0, European Commission 2013). In many stands abundant development of dense undergrowth, in particular, hazel Corylus avellana and hornbeam Carpinus betulus, shades out the rich oakwood herbaceous layer and the woodland becomes dominated by shade-tolerant species as a form of Tilio-Carpinetum (Jakubowska-Gabara 1996).

The decline of this thermophilous community has taken place in the time of global warming which points to the involvement of other factors, such as the change of the photoclimate caused by the change of management regime. In the Białowieża Forest Faliński (Faliński 1986, pp. 210-213) attributed the decline to the excessive grazing at the turn of the 19th and 20th centuries. However, the opposite seems more likely, with either spontaneous ecological succession following the ban on forest grazing or active forest management to create dense closed-canopy stands, leading to the disappearance of shade-intolerant species (Roleček 2005; Samojlik et al. 2016; Bobiec et al. 2018; Vera 2000).

Bruun and Fritzbøger (2002) provide strong evidence of the role of historical transhumant pastoralism in the spread of plants through landscapes and wider regions. Forests and woods were commonly open for grazing (Rackham 1980; Vera 2000; Rotherham 2013; Varga et al. 2016) and so were strongly interconnected with other components of variegated rural landscapes (Poschlod and Bonn 1998). The exceptional richness of thermophilous oak woods, involving both forest and grassland species, was a consequence of disturbance regimes that both slowed the progress of ecological succession and encouraged the import of grassland species, thus enriching the forest flora (Öllerer et al. 2019).

Endo- and exo-zoochoric dispersal was likely to have been a key-factor in spreading diaspores to communities and sustaining their richness (Chabrerie et al. 2013; Couvreur et al. 2004; Ozinga et al. 2005). Excluding woodland from grazed areas and replacing free-range husbandry with set stocking or intensive indoor animal production have greatly reduced or even halted this interchange of species and genes across the landscape and led to progressive impoverishment of plant communities (Bonn 2004; Öllerer et al. 2019).

The eastern part of Subcarpathia, has preserved the legacies of partly wooded integrated cultural landscapes better than in Western and much of Central Europe due to the long history of silvo-pastoral land use, relatively recent socio-demographics and institutional shifts (Munteanu et al. 2014). In central and western Europe, rural landscapes have long been split into segregated domains of modern forestry and agriculture. However, even in eastern Subcarpthia, are these recognizable structural features, the semi-open oakwood marginal stands (Bobiec et al. 2019), still accompanied by the expected mix of both 'grassland' and 'woodland' species?

We have addressed this question using the "natural experiment" of two sub-carpathian regions with contrasting recent landscape history: one with relatively old oak-dominated margins of ancient woods, regularly visited by livestock by the mid-1900s; the second where, at the same time, the historic wood-pastures have been transformed to semi-open oak groves immersed in vast, recently abandoned arable fields. We hypothesize that in the former case, where grazing abandonment was not compensated with proxy measures, spontaneous development of dense undergrowth would lead to a shift towards more shade-tolerant communities and a reduced or extirpated grassland element. In the latter case, however, where the tree canopy openness has fortuitously been maintained through recurring 
early spring fires, light conditions should be more favourable for the permanent presence of shade-intolerant species, including the ones from the adjacent grassland.

Oak as a non-forest opportunist, is a major contributor to temperate European woodpastures' treescape (Bobiec et al. 2018), and we therefore expect a stronger grassland flora representation under the oak-dominated canopy than under trees casting a heavier shade. However the light-demanding species may not permeate efficiently enough into the wooded ecotone in the absence of regular grazing. Does the herbaceous species composition of the woods - in particular, with respect to grassland species and to the "ancient forest" floracorrespond with their tree species composition? Our addressing of these questions may help to develop the necessary "transformation strategy", providing a modern efficient substitution of the traditional husbandry in its invaluable role of fostering central and eastEuropean oakwoods.

\section{Sites and methods}

The study involved ten sites, five in the Przemyskie Foothills, ca. $20 \mathrm{~km}$ south from Przemyśl town of (SE Poland), and five on Ciscarpathia's (also called 'Prycarpattya') undulating plateau, ca. $45 \mathrm{~km}$ west from the town of Ivano-Frankivsk, Rozhniativ county (W Ukraine) (Fig. 1). Both regions have temperate climatic and mesic site conditions (Table 1).

\section{Land-use history}

In the nineteenth century and up to the end of World War I both areas were subject to the Austrian-Hungarian land-use rules and between WWI and WWII to the Polish government rules. In the Przemyskie Foothills (P) the more diverse topography combined with less acidic soils favoured the formation of a distinct mosaic of arable fields, grasslands and woods, whereas the Prykarpattya's landscapes (U) were chiefly managed as wood-pastures (Plieninger et al. 2015). This difference is clearly shown on the historical military maps of the mid-1800s (Timár et al. 2006; https://mapire.eu/en/map/europe-19century-secondsurv ey).

Until World War II, the population of the Przemyskie Foothills region was several times larger than it is at present, with each household keeping on average 3-4 cows, that were grazed on common pastures including the woodland margins (Affek 2015; Bułat, pers. comm.). After the war, under the Soviet regime, most of the woods were acquired by the State Forest Holding, which encouraged the conversion of grazed semi-open oak woods to dense high forest stands to produce timber. The arable fields were gradually turned into grassland and in the early 1970s, grazing within the woodland was legally banned. A dendroecological reconstruction study found that this coincided with the ending of oak wood recruitment in the landscape (Bobiec et al. 2019).

After WWII the Prykarpattya countryside followed a different trajectory. The establishment of the Soviet agri-cooperatives ("kolkhoz") and state's farms ("sovkhoz") entailed the conversion of the vast tracks of grasslands to arable land, but the villagers kept using the remnants of wood-pastures as treed hay meadows until the mid-1980s (M. Korol, pers. comm.). The collapse of the Soviet Union led to the abandonment of the arable fields, so that there was then a surplus of forage for the local livestock. Hay-making in the less-productive "treed meadows" was abandoned. In order to improve the forage quality of the 


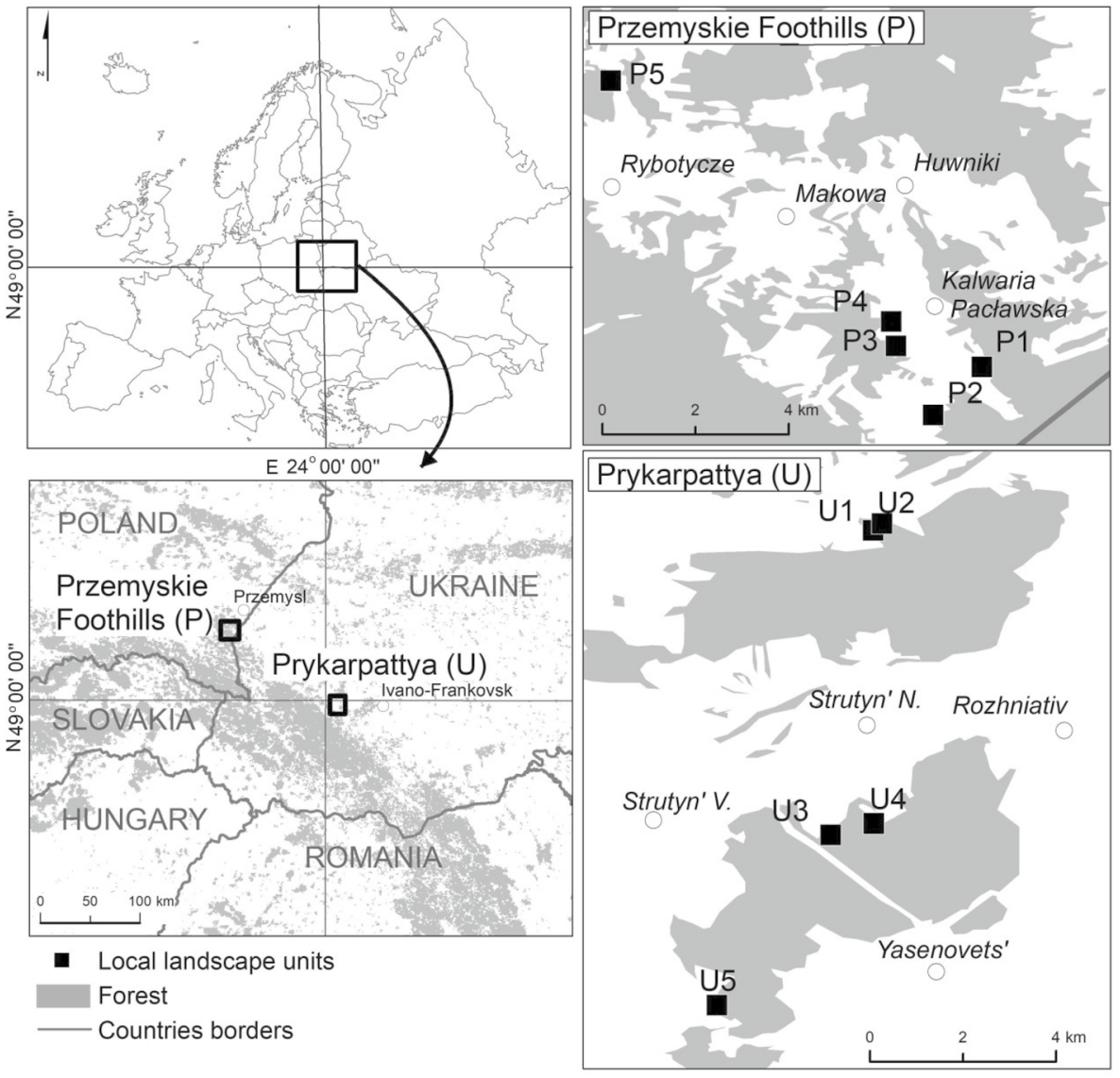

Fig. 1 Location of two study regions and ten study sites

successional herbaceous communities, they are now regularly burnt in early spring to remove dry dead material, even though this practice is illegal. The fires commonly spread into the neighbouring oakwoods, maintaining their semi-open structure of the grasslandwoodland interface (Fig. 2), (Bobiec et al. 2019).

\section{Sampling design and data acquisition}

\section{Local landscape data}

In each region, we selected the five best-preserved patches of oak wood (i.e. with the tree canopy layer dominated by "wild"-grown, wide-crowned oaks) with adjacent grassland areas and a $500 \mathrm{~m}$ wide circular buffer (78.5 ha) was then drawn based on the centroid of each oakwood patch. Historic and present-day land-use maps were produced for each buffered area, using the Second Military Survey maps of the Habsburg Empire (1806-1869) (Timár et al. 2006), the map of the (Polish) Military Geographical Institute (1919-1939), and the contemporary orthophoto imageries available in Google-Earth Pro software. Polygons were digitized classifying the land use into one of three broad categories: woodland, 


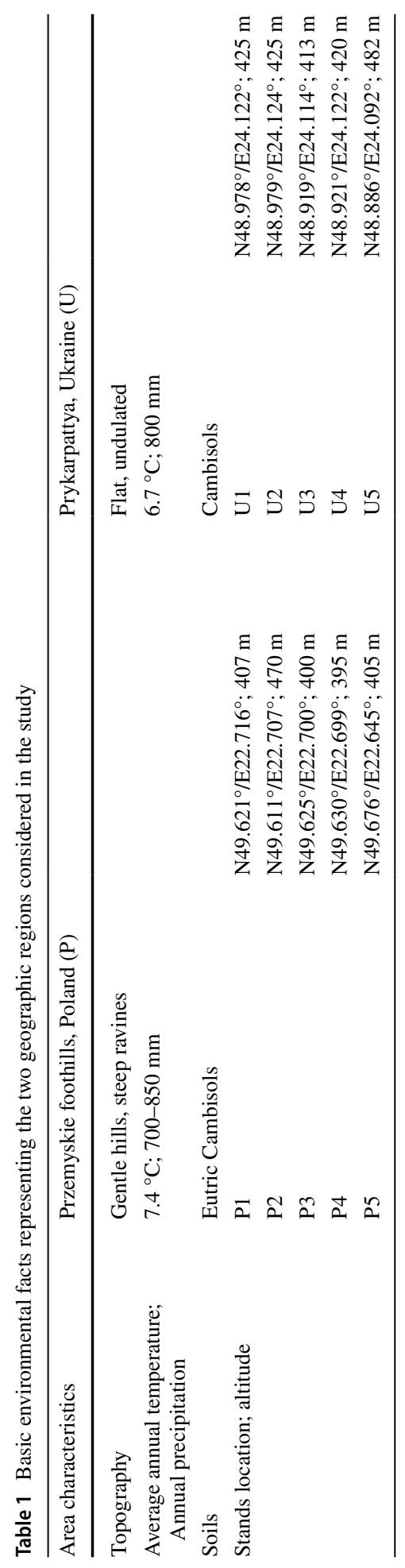



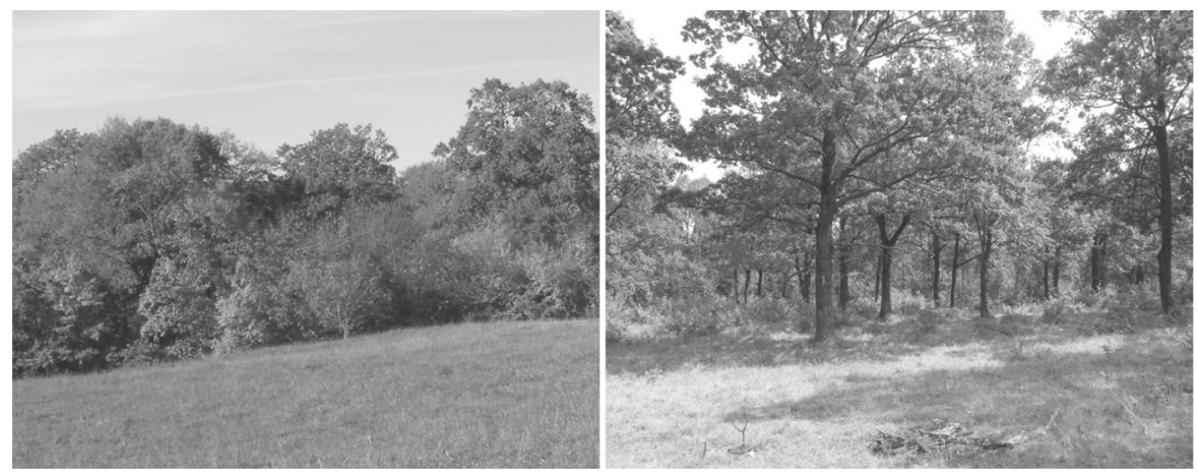

Fig. 2 The "sealed-off" border line between grassland and woodland in Przemyskie Foothills (P3G/P3F, left) vs. ecotonal oakwood zone in Prykarpattya (U1G/U1F, right)

grassland (including treed-grasslands) and arable land (Fig. 3). Based on the concept of the 'oakscape' (Bobiec et al. 2018), we regarded the oakwood development as pivotal in the recent trajectories of the local landscapes. Each oakwood stand is represented by its recruitment period, i.e. the timespan between the calendar year in which the oldest oak of the existing population (including the dated stumps) had reached the height of $1.3 \mathrm{~m}$ above the ground level, and the year when the youngest oak did the same. The central years of the stands' recruitment periods, were estimated from a dendro-ecological reconstruction summarised in the next section. The structure of the local landscapes at central stands' recruitment years were then linearly interpolated from the mapping surveys previous to and following the recruitment years for that landscape.

\section{Dendro-ecological reconstruction of the oak stands}

The oak stand recruitment phase was defined from the distribution of the calendar years when the present oaks (living or dead, including stumps) grew above the "breast height" level, i.e. $1.3 \mathrm{~m}$. We selected at least 30 random trees in each stand for sampling with a 5 -mm Pressler's increment borer at $1.3 \mathrm{~m}$. Wherever hard stumps were present, we cut wood discs from them. The wood samples were glued to wooden slats, polished with 500-p sandpaper, and the rings were measured with the LINTAB-5. All dead tree (chiefly discs) series were cross-dated and checked against the local life-oak cores with TSAP-Win v. 4.65 software (Rinn 2003). For stump discs, the 1.3-m 'recruitment year' was assumed to be four years later than the original 0.2-m stump's 'pith year' (the median time lag between 0.2 and $1.3 \mathrm{~m}$, found in 59 oak samplings, Bobiec, unpubl.). If the pith was missing, we used the pith-finder stencil to estimate the gap's length and to calculate the number of missing oldest rings (Rozas 2003). Wood cores with more than 15 missing innermost rings were excluded from the analyses.

\section{Phytosociological data}

The plant communities in both the oak patches and adjacent grassland were surveyed at the end of June in 2016 (Przemyskie) and in mid-July, 2017 (Prykarpattya) (Electronic Supplementary Material, ESM.data). Prior the sampling, the zones were subjected to preliminary 
eye-inspection aimed to identify possible distinct vegetation patches (or synusiae, sensu Bobiec 1998), contributing to the communities internal heterogeneity. At each of the five locations in each region a $100-\mathrm{m}$ long and $60-\mathrm{m}$ wide peripheral zone along the oakwoodgrassland border was delimited- $-30 \mathrm{~m}$ into the grasslands and $30 \mathrm{~m}$ into the woods from the grassland-woods borderline connecting the outer points of the woodland canopy projection. This distance was sufficient that the grassland plots were not directly shaded by the forest edge, while the woodland plots would be beyond most direct effects of the open ground (increased side-light, reduced humidity). On either side of the border line (the outer limit of the canopy trees) five (in very homogenous grasslands) to eleven (in the most heterogenous woodland community) $10 \times 10 \mathrm{~m}$ quadrats were recorded, giving a total of 168 relevés. In order to cover the existing spatial variability of the studied communities, the quadrats were positioned with the stratified sampling method (Newton 2007).

Species abundance in each quadrat was assessed with Braun-Banquet's (Braun-Blanquet and Pavillard 1925) six-interval area coverage ranks: "+" (replaced with 0.5 in quantitative analyses) <1\%, "1" 1-5\%, "2" 6-25\%, "3" 26-50\%, "4" 51-75\%, "5"> 75\%, separately for each layer: tree canopy (height $>5 \mathrm{~m})$, understorey $(>0.5-5 \mathrm{~m})$, and ground layer ( $\leq 0.5 \mathrm{~m}$, but also including species such as Rubus fruticosus that may sometimes grow taller). The ground layer species were assigned to their characteristic habitat(s) i.e. forests FOR, thickets THI, forest edges and glades EDG, clearings CLE, scrubland SCR, xerothermic grasslands XER, damp meadows and pastures MEA, ruderal habitats RUD, croplands (segetal weeds) SEG, and wetlands WET based on the Polish flora (Szafer 1953). Most species were associated with more than one habitat, so we developed four exclusive combined habitat groups: (1) Forest (specific), i.e. FOREST species not associated with CLE or SCR or XER or RUD or MEA or SEG), (2) Forest non-specific, i.e. FOREST species also associated with habitats excluded from (1), (3) Open-habitat (specific), i.e. any of species associated only with one of the habitats excluded from (1), (4) Open-habitat non-specific, i.e. species associated with SCR or XER or RUD or MEA or SEG, as well as with THI or EDG.

We also refined the Forest (FOR) category, distinguishing "ancient forest/woodland species" (OLD), using a dataset compiled from seven sources (Froment and Tanghe 1967; Peterken and Game 1984; Dzwonko and Gawroński 1994; Hermy et al. 1999; Verheyen et al. 2003; Wulf 2003; Marage et al. 2006). A species was considered as an ancient forest/ woodland species only if it was identified as such by at least three authors. In the statistical analyses, ancient forest/woodland species that were also associated with other types of habitat according to Szafer (1953) were weighted by factor 0.5 .

Matuszkiewicz (2008) considered that Tilio-Carpinetum would dominate the Przemyskie Foothills as the main type of potential vegetation (Online source 1). We therefore included in the analyses ten relevés representing Tilio-Carpinetum, Małopolska vicariant, submontane form with subassociations: T.-C. corydaletosum (TCc) and T.-C. typicum (TCt) from Kozłowska's (2000) study, representing Tilio-Carpinetum. All had a substantial amount of oak in the tree canopy layer.

\section{Data analysis}

We excluded the tree and shrub canopy layer data in the comparative analyses because we were primarily interested in the herbaceous response to the different management histories which might be mediated by the woody layers, e.g. through varying levels of shading. The canopy tree and shrub species present as seedlings and short saplings were also 
Fig. 3 Ten circular 78.5-hectare local landscape units in the context of historical cartographic data (mid1850s 2nd Austro-Hungarian military survey; 1920s/1930s (Polish) Military Geographical Institute (19191939)) and recent ortophoto maps

excluded from the ground layer because they are only transient components of the ground layer pattern.

The 178 relevés (168 of our quadrats and 10 from Kozłowska 2000) were subjected to unconstrained ordination by detrended correspondence analysis (DCA, Hill and Gauch 1980) based on the abundance of species in the ground vegetation layer. Based on the first two axes values, we performed the k-means clustering of the relevés. The predefined number of clusters - four-referred to the four major grouping variables: Przemyskie Foothills woodland (1) and grassland (2), Pryparpattya woodland (3), and grassland (4). The grouping of species was based on their affiliations with four exclusive combined habitats groups: Forest (specific) (1), Forest non-specific (2), Open habitat (specific) (3), and Open habitat non-specific (4).

We performed the Kruscal-Wallis anova in order to compare the distributions of $\mathrm{L}$ (light), R (soil reaction), and N (nitrogen) Ellenberg values (Ellenberg et al. 1992) between eleven sets of species representing the different types of habitats (OLD, FOR, .., WET). Because most of the species have more than a single habitat type affiliation, these sets partly overlapped.

In order to identify the influence of historic land-use changes and the effect of the tree and tall shrub layer on the herbaceous vegetation of the oakwood communities alone (ninety relevés across the two regions), we performed the redundancy analysis (RDA, Van den Wollenberg 1977). We used as explanatory variables, the tree layer characteristics (oak canopy cover; total canopy cover of shade-tolerant trees; total canopy cover of pioneer tree species; canopy cover of tall shrubs, chiefly hazel; stand age) and the per-annum changes in the proportion of woodland, grassland, and arable land since the median year of the oak wood recruitment and the following cover values. The response variables were the joint frequencies (per relevé occurrences) of all herb layer species representing particular species groups (Forest, Thicket, Grassland etc.).

For data management and writing we used WPS Office (Kingsoft), DCA and RDA were carried out with CANOCO 5 (Software for multivariate data exploration, testing, and summarization written by Cajo JF ter Braak and Petr Smilauer (c) 1997-2013 Biometrics, Plant Research International, The Netherlands, and Petr Smilauer, Czech Republic). Other statistical analyses have been made with Statistica 13.2 (Dell ${ }^{\mathrm{TM}}$ Statistica $^{\mathrm{TM}}$ ), whereas for digitizing historical maps and imagery we used QGIS 3.14.

\section{Results}

\section{General description}

\section{Tree dynamics}

In the Przemyskie foothills, tree recruitment was completed by 1950s and oak has largely lost its dominant position to late successional tree species and tall shrubs, whereas most of the Prykarpattya's much younger oak stands still showed recruitment potential for oak (Table 2). 


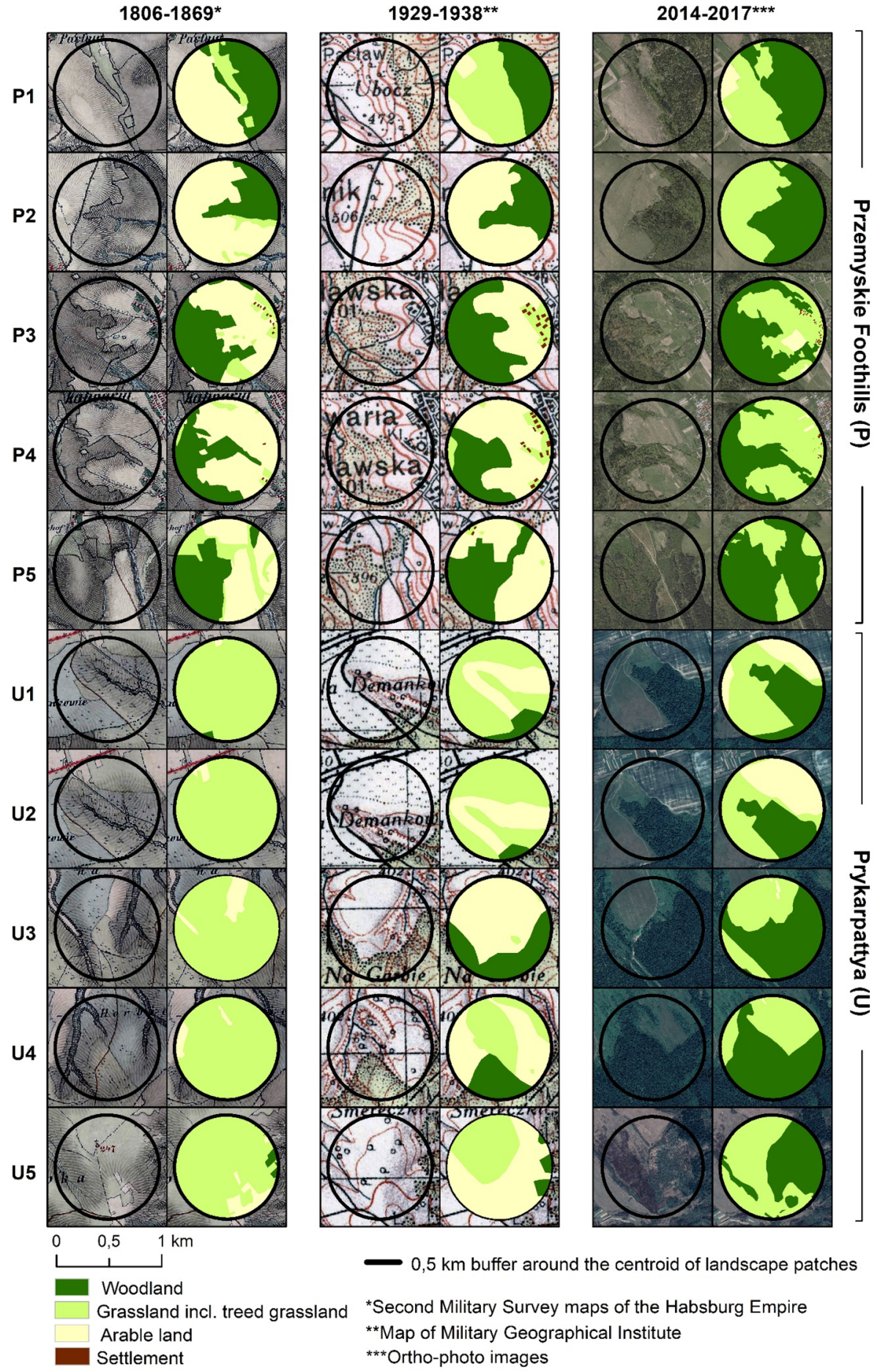


Table 2 Description of oak wood patches: $\mathrm{N}$-number of sampled oaks; IQR-inter-quartile range of the oak recruitment years (calendar years of saplings reaching height of $1.3 \mathrm{~m}$ ); Median-median of the oak recruitment years; \%CC - tree canopy cover; Gen-general; QU(\%Gen) percent of oak in \%CC; ACS(10)—accompanying canopy species with the \%CC share $\geq 10 \%$; ABAL - Abies alba, ACPS - Acer pseudoplatanus, CABE - Carpinus betulus, FASY-Fagus sylvatica; ug-undergrowth; hb-herb layer; qu-oak saplings taller than $0.5 \mathrm{~m} ;+$ scarce; +++ abundant

\begin{tabular}{|c|c|c|c|c|c|c|c|c|c|}
\hline \multirow[t]{2}{*}{ Stand } & \multirow[t]{2}{*}{$\mathrm{N}$} & \multirow[t]{2}{*}{ IQR } & \multirow[t]{2}{*}{ Median } & \multicolumn{2}{|c|}{$\% \mathrm{CC}$} & \multirow[t]{2}{*}{$\operatorname{ACS}(10)$} & \multirow[t]{2}{*}{ ug } & \multirow[t]{2}{*}{$\mathrm{hb}$} & \multirow[t]{2}{*}{ qu } \\
\hline & & & & Gen & QU(\%Gen) & & & & \\
\hline P1 & 57 & 1906-1918 & 1913 & 60 & 75 & ABAL, ACPS & +++ & $+* *$ & \\
\hline $\mathrm{P} 2$ & $29 *$ & 1941-1948 & 1943 & 100 & 50 & ABAL, FASY & ++ & + & \\
\hline P3 & $26^{*}$ & $1860-1883$ & 1862 & 60 & 50 & FASY, CABE & +++ & + & + \\
\hline P4 & 47 & $1873-1883$ & 1877 & 30 & 60 & FASY, ABAL & +++ & + & + \\
\hline P5 & 41 & $1854-1870$ & 1863 & 70 & 90 & - & +++ & + & \\
\hline U1 & 37 & 1900-1944 & 1925 & 60 & 95 & - & ++ & +++ & ++ \\
\hline U2 & 30 & 1926-1949 & 1941 & 70 & 95 & - & +++ & + & + \\
\hline U3 & $27 *$ & 1947-1956 & 1952 & 40 & 95 & - & ++ & +++ & +++ \\
\hline U4 & 34 & 1947-1965 & 1954 & 60 & 85 & - & ++ & +++ & ++ \\
\hline U5 & 34 & 1975-1990 & 1984 & 40 & 85 & - & + & +++ & ++ \\
\hline
\end{tabular}

* Sample size was lower than N30 due to the rejection of wood series with more than 10 missing inner rings or other reasons preventing the accurate pith year identification

**After the hazel removal in the part of the P1 stand in 2012-2015 the local hb cover reached +++

Across all the 178 relevés (including the 10 'reference' Tilio-Carpinetum) 349 herbaceous layer vascular plant species were recorded, plus 27 tree and shrub species (see

Table 3 Overlap between species-habitat categories: OLD—ancient forest, FOR-forest, THI-thicket, EDG_-forest edge, CLE—clearing, glade, SCR — scrubland, XER—xerothermic grassland, RUD—ruderal vegetation, MEA — meadow, SEG — segetal weeds vegetation, WET—wetland

\begin{tabular}{llllllllllll}
\hline & OLD & FOR & THI & EDG & CLE & SCR & XER & RUD & MEA & SEG & WET \\
\hline OLD & $\mathbf{4 0}$ & 40 & 25 & 8 & 4 & 1 & 1 & 5 & 3 & 0 & 4 \\
FOR & & $\mathbf{1 6 7}$ & 96 & 20 & 23 & 14 & 15 & 30 & 21 & 2 & 25 \\
THI & & & $\mathbf{1 4 9}$ & 21 & 21 & 5 & 38 & 47 & 29 & 8 & 16 \\
EDG & & & & $\mathbf{4 6}$ & 6 & 8 & 10 & 16 & 8 & 3 & 5 \\
CLE & & & & & $\mathbf{4 2}$ & 2 & 11 & 16 & 10 & 3 & 7 \\
SCR & & & & & & $\mathbf{4 2}$ & 10 & 16 & 23 & 0 & 1 \\
XER & & & & & & & $\mathbf{8 4}$ & 41 & 20 & 19 & 0 \\
RUD & & & & & & & & $\mathbf{1 1 3}$ & 27 & 13 & 14 \\
MEA & & & & & & & & & $\mathbf{7 7}$ & 2 & 8 \\
SEG & & & & & & & & & & $\mathbf{3 6}$ & 8 \\
WET & & & & & & & & & & & $\mathbf{7 4}$ \\
\hline
\end{tabular}

Bold values refer to the overal numbers of ground layer species identified as "ancient forest species", "forest species", ... (according to the firstcolumn categories) and non-bold values to the overlaps (common) for the particular pairs of categories. No significance test involved 
Online source 1). Of the herbaceous layer species 167 species were associated with forests and 149 with thickets (96 with forests and thickets). Only 40 were considered to be ancient forest species (Table 3). When comparisons were made using Ellenberg scores for different species groups, not surprisingly, the sharpest difference between the types of habitats referred to light conditions, with the ancient forest and forest categories being the most shade tolerant (see Electronic Supplementary Material—ESM.data).

\section{Ecological overlap between the neighbouring oakwoods and grasslands}

Detrended correspondence analysis (DCA) revealed strong clustering of groups of relevés along axes 1 and 2 . The woodland plots from the two regions are almost completely separate; the grassland samples are much more similar across the two regions. Some of the Przemyskie foothills oakwoods are strongly related to the "model" Tilio-Carpinetum, but another part form a separate cluster, at a closer DCA1 distance to the grassland relevés. Despite the grassland and Prykarpattya's woodland clusters separateness, there is a clear connecting bridge with a strong affinity shared by parts of the Prykarpattya's grassland and woodland relevés. Amongst the species, there are almost separate clusters of forest and open-habitat specific species but strong overlap between intermediate forest and open habitat non-specific clusters (Fig. 4).

Forest-specific species (as defined by the national flora) are most abundant in the forest plots and open-habitat specific species in the grassland plots (Table 4), but there is considerable overlap of the floras across the grassland/woodland boundary.
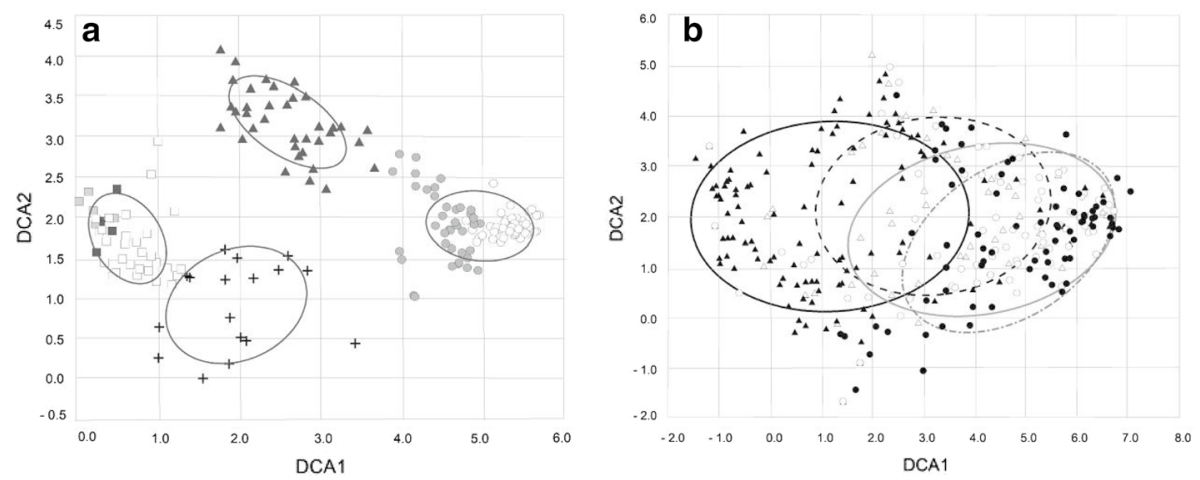

Fig. 4 a DCA1 vs. DCA2 ordination of 178 relevés, based on the abundance data of 349 herb layer species; triangles-UA oakwood relevés, grey circles-UA grassland relevés, blank circles-PL grassland relevés, crosses-PL underdeveloped wooded communities, blank squares-PL Tilio-Carpinetum relevés, black squares-PL Tilio-Carpinetum corydaletosum reference relevés (from Kozłowska 2000), grey squares-PL Tilio-Carpinetum typicum reference relevés (from Kozłowska 2000); b distribution of herb layer species representing four exclusive habitat clusters: Forest (black triangles, solid dark ellipse), Forest non-specific (blank triangles, dashed dark ellipse), Open-habitat specific (black circles, dash-dot light ellipse), Openhabitat non-specific (blank circles, solid light ellipse); standard deviational ellipses illustrate the spatial characteristics of four distinguished groups of relevés: central tendency, dispersion, and directional trends (Wang et al. 2015) 
Table 4 Richness and frequency of four exclusive categories of herbaceous species in grassland and forest relevés; Forest—forest (specific) habitat, Forest NS—forest non-specific habitat, Open-open habitat (specific), Open NS—open habitat non-specific

\begin{tabular}{lll}
\hline Herbaceous species category & $\begin{array}{l}\text { No. of species (frequency) in grassland } \\
\text { relevés }(\mathrm{N}=78)\end{array}$ & $\begin{array}{l}\text { No. of species (frequency) } \\
\text { in forest relevés }(\mathrm{N}=90)\end{array}$ \\
\hline Forest & $25(3.3)$ & $87(11.9)$ \\
Forest NS & $29(5.7)$ & $43(4.9)$ \\
Open NS & $57(13.6)$ & $57(3.7)$ \\
Open & $67(9.0)$ & $48(2.5)$ \\
\hline
\end{tabular}

\section{Stands characteristics in the context of landscape history}

The two regions differ in how the land was used in the past and in the subsequent changes. The Przemyskie Foothills were quite well-wooded according to the Austro-Hungarian mid1800 s' military maps (15\% to ca. $45 \%$ ), with high levels of arable and little grassland. By contrast in Prykarpattya treed grassland dominated the landscape and woodland and arable were almost absent (Fig. 5). We detected no major change in the landuse prior the emergence of other oakwoods of the Przemyskie Foothills except for PL1, where the oak stand development was preceded by the sharp increase of grassland acreage at the expense of arable. In Prykarpattya there was a decline of treed grasslands in all five units. From almost no forest present in the Ukrainian "baseline" landuse structure, oak recruitment in sections of treed grassland resulted in the appearance of the forest category in subsequent surveys. Since the oakwoods establishment until 2010, the arable acreage has declined in both Przemyskie Foothills and Prykarpattya, while the forested area continued to expand in almost all ten landscape units (Fig. 5).

The total RDA variance explained by the considered explanatory variables was only moderate $(38.2 \%)$, but several meaningful patterns can be detected (Fig. 6). The two most influential explanatory variables, i.e. the total canopy cover of shade-tolerant trees (mainly hornbeam, beech, and maples) and hazel are the strongest blockers of seven nonforest affiliation types (scrub and xerothermic community, woodland edge and forest clearing, meadow, segetal weed assemblage, and wetland). They are positively correlated with the stands' age as well as with the annual increase in the grasslands share GrYr, but both these latter explanatory variables had only a limited and insignificant contribution (Fig. 6). Somewhat counter intuitively, the strongest negative predictor for the species groups OLD and FOR was - the annual increase in woodland cover (WdYr), correlating, however, with the share of pioneering trees in the woodland canopy. Unlike for heavy shade-casting trees, the oaks' canopy was not negatively linked to the non-forest affiliation species types (Fig. 6).

\section{Discussion}

The two regions, Przemyskie Foothills and Prykarpattya, are both rich in marginal oakwoods adjacent to open agricultural land but with different, relatively well-known, recent histories of land use, forming a quasi-natural "experiment" (sensu Diamond 1986). In both 


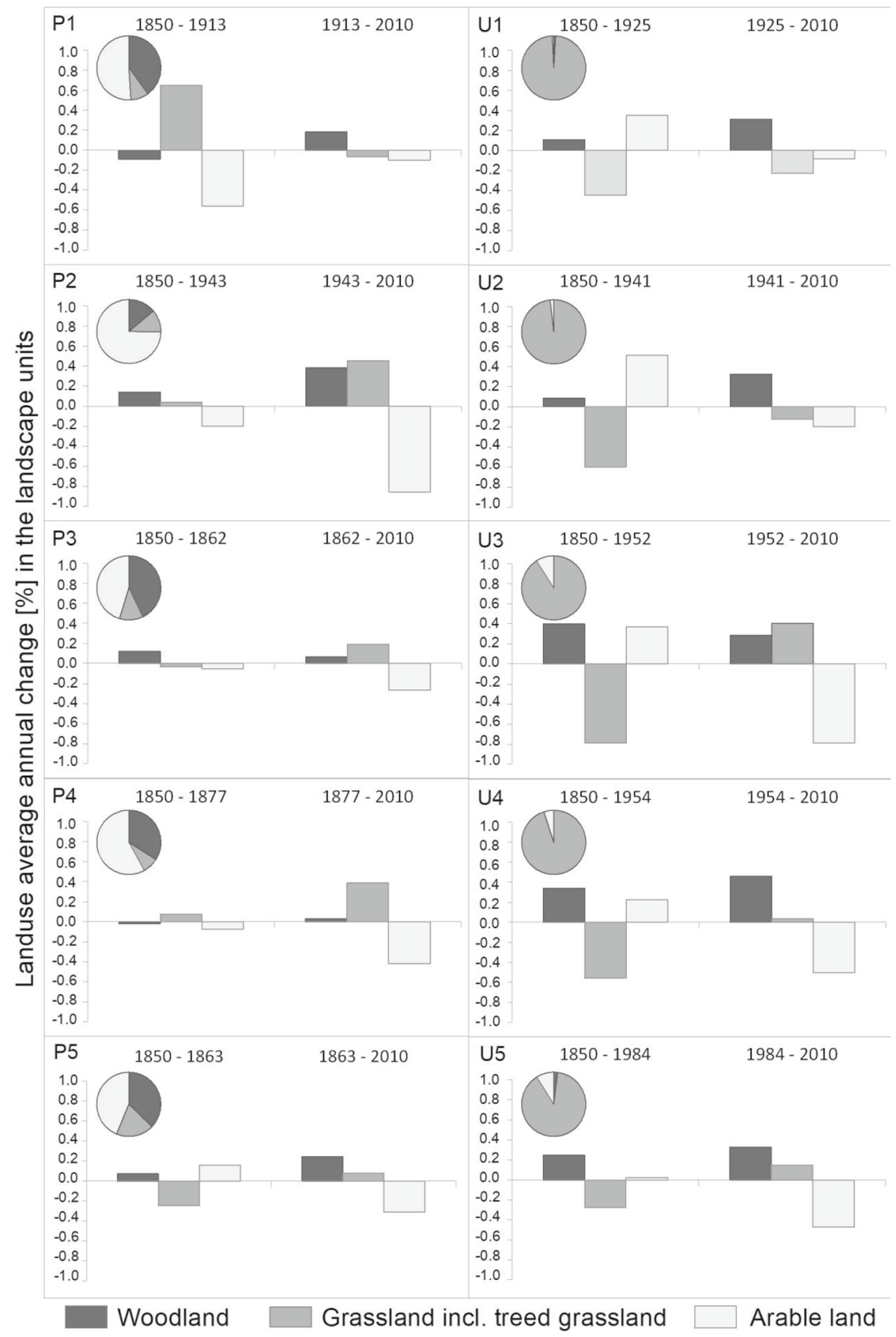

Fig. 5 The average annual landuse change (AALC) in particular landscape units. Pie charts refer to the local landuse structure according to the 2nd Habsburg Military Survey (baseline references); two sets of columns, representing the AALC in particular landscape units between the 1850s' "baseline" and the central oak stands recruitment years (Table 2) — the first set, and between the central recruitment years and the 2010's satellite imageries-the second set; P1-5 (Carpathian foothill), U1-5 (Prykarpattya); see Fig. 3. for the digitizing process 


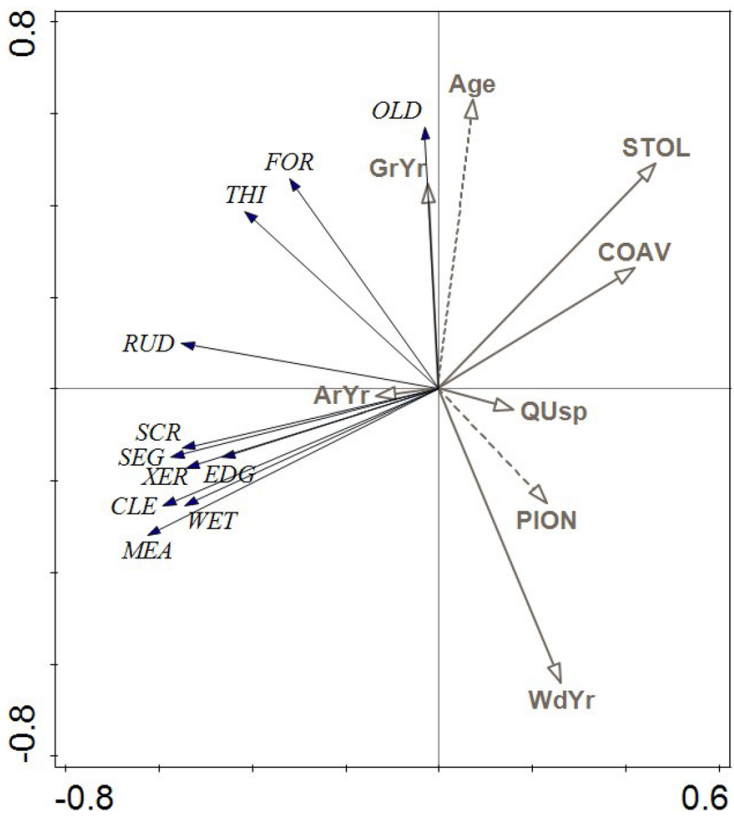

Fig. 6 The RDA biplot revealing correlations between the selected predictors (explanatory variables-light grey empty arrows; dashed lines $\mathrm{p}>0.05)$ and response variables-black arrows: STOL $(21.6 \%$ of contribution, $\mathrm{p}=0.006$ ) — total canopy cover $(\mathrm{CC})$ of shade-tolerant trees; COAV $(16.4 \%, \mathrm{p}=0.002)$ - tall shrub (chiefly hazel) CC; WdYr (25.5\%, p=0.002), GrYr (5.2\%, p=0.076), ArYr (14.3\%, p=0.006)-per-annum percent change of woodland/grassland/arable land cover since the median year of the oak stand recruitment; QUsp-oak CC (8.6\%, p=0.030), PION (4.5\%, p=0.126)—pioneering trees CC; Age $(3.9 \%, p=0.154)$ median age of the oak stand; species associated with OLD_-ancient forest species, FOR forests, THI thickets. $E D G$ forest edges, $C L E$ clearings, $R U D$ ruderal habitats, $S C R$ scrublands, $X E R$ xerothermic grasslands, $M E A$ meadows, SEG crop weeds communities, WET wetlands

cases the oakwoods have developed spontaneously. There was clear separation of communities defined by their herb layer composition by habitat type (woodland vs. grassland) but also by geographic region (Przemyskie Foothills vs. Prykarpattya) (Fig. 4). In both regions 'grassland' species survive within the oak woodland and forest species occur out in the grassland. However, there are differences relating in part to differences in recent landscape history.

The landscape of the Przemyskie Foothills has had consistently a higher cover of woodland throughout the last 150 years-or-more (Fig. 5; Timár et al. 2006); surroundings of the village Kalwaria Pacławska: https://mapire.eu/en/map/europe-19century-secondsurvey, check "Kalwaria Paclawska" in "Search this map" window; Online source 2). Until 1945, the high population in the villages and numerous small farms was reflected in the dominance of arable farmland (Fig. 5). However, with 3-4 cows per household on average and a shortage of open grasslands, forest margins were important grazing areas (Affek 2015; Bobiec et al. 2019). Following the post-war dramatic, ten-fold, depopulation, woodland grazing has substantially decreased, being ultimately extirpated by the legal ban on forest grazing imposed in all Polish forests in early 1970s. The oakwoods had a relatively high frequency of ancient woodland species, but parts of them were still generally distinct (little overlap in the DCA) from the composition of the Tilio-Carpinetum (whether T-C 
corydaletosum or T-C typicum) communities (such as recorded by Kozłowska 2000), considered the 'potential natural vegetation' (Matuszkiewicz 2008). The lower share of both forest and ancient forest species compared to the Tilio-Carpinetum data, from the same region corresponds with the so-called "colonization credit" effect (Burst et al. 2017), i.e. there is the potential habitat for these species but they have not yet colonized because of the poor dispersibility of ancient forest species (Hermy et al. 1999).

Prykarpattya, has had a different history. On the mid-1800s' map (Timár et al. 2006; surroundings of Rozhniativ town: https://mapire.eu/en/map/europe-19century-secondsurvey, check "Rozhniativ" in "search this map" window; Online source 2), there is little woodland but trees are present as wood-pastures or treed meadows. There was a steep decline in such treed grasslands, with many transformed into arable fields, under the Soviet policy of the corporate farms. Other former wood-pastures, have been the subject to slow woodland succession, although some were still grazed by individual farmers until the late 1970s (Bobiec et al. 2019, supported by Korol's witness account). The semi-open character of most of these oakwoods, which favours continuing slow oak recruitment, has been sustained by the common practice of spring grass burning (Bobiec et al. 2019; Ziobro et al. 2016). This more open character is reflected in their closer alignment to the grassland communities on the DCA plot. Their generally younger origin and isolation from ancient forests also helps to explain the lower number of forest and ancient woodland species compared to the Przemyskie oakwoods.

The structure of the landscapes studied here, is similar to a comparison of two landscape patterns reported from Swiss Jura by Peringer et al. (2016). There they found that under the lower grazing pressure more shade-tolerant trees (such as beech) tend to establish dense groves segregated from grassland, while the heavier grazing pressure results in vast ecotone areas sparsely wooded by less shade-tolerant species.

In Przemyskie the post-war collapse of the traditional silvopastoralism coupled with a legal ban on forest grazing created ideal conditions for swift recovery of much of the TilioCarpinetum "potential vegetation", although some species are still absent; this a lot prevented further colonization and reduced survival of the rich heliophilous herbaceous flora (Figs. 2, 6).

In Prykarpattya, despite the sustained semi-open canopy structure of oakwoods, the grassland species remained few. Unlike in the past there are few large mammals to move seeds from the grassland into the forest; there is a lack of mechanism for the spill-over of species from one habitat to another (Ries and Sisk 2004), contributing to the woodland floristic richness in cultural landscapes (Poschlod and Bonn 1998). Forest grazing is still legal in Ukraine, but we saw little evidence of the livestock visits under tree canopy. Burning alone, though preventing the development of a dense undergrowth and maintaining the semi-open woods' character, cannot be considered a substitute of grazing (Öllerer 2014).

During the Soviet period, the treed grassland was often converted to arable. Many have gone back to grassland during the last few decades, but this woodland may not have the same level of species richness as formerly. In the Przemyskie Foothills, the principle resource of available fodder were communal pastures, which, even after the collapse of traditional husbandry have often retained their ancient grassland character (Burst et al. 2020). 


\section{Conclusions and recommendations}

Semi-open oakwoods, were once a common feature of European agricultural landscapes. Certain elements of the ancient oak groves can be preserved in segregated forest and grassland habitats (such as ancient forest species vs. ancient grassland species), but semi-open oakwoods combine these with a wide range of more generalist forest and grassland species well beyond the immediate edge zone. This richness seems to have depended on the movement of animals, by which plant species are moved between grassland and woodland-the "spill-over" mechanism (Ries and Sisk 2004). The successful establishment of the open habitats species under the oakwood canopy is further encouraged by a suitable "habitat enhancement" (Ries and Sisk 2004), suppressing the undergrowth development and securing a certain level of the tree canopy openness. This traditional woodmanship—pollarding of the trees combined with grazing-helped to sustain local subsistence farms (Rackham 1980).

To restore this type of functioning we need to encourage: (1) "unsealing" (or "softening") the "sharp" forest-grassland interface (Herlin 2001), leading to more permeability for species migration (Chabrerie et al. 2013; Burst et al. 2017); (2) reduction of the degree of canopy closure; and (3) restoration of woodland grazing, to secure efficient import of grassland species into the opened-out oakwood habitats (Bonn 2004).

High-conservation value semi-open zoo-anthropogenic oakwoods, subject to unsuitable silvicultural treatment or to ill-suited conservation measures, belong to the most endangered wooded habitats in Europe (Bergmeier et al. 2010). Restoring ecotonal grasslandwoodland zones would be an efficient way in which semi-open oak-dominated woods could be returned to our rural landscapes. Therefore, the grassland-woodland ecotones restitution should become a priority for Europe's further conservation efforts, as part of re-connecting sustainable farming with the ecology of the surrounding landscape. This is difficult to achieve by grant-based initiatives, which cannot be used as a lasting efficient remedy on the landscape scale (Sayer et al. 2013). A "transformation strategy", restoring local scale farming, building on the natural potential of landscapes and their habitats, may lead to enduring effects (Fischer et al. 2012). The eco-historical experience of forest grazing might be used as a blueprint for opening-up the marginal zones of woods to the restorative effect of livestock grazing (Öllerer et al. 2019).

Acknowledgements We express our thanks to two anonymous Reviewers for their invaluable comments and advice. The financial support was received through the project 'Oak woods in rural landscapes of the Carpathian region: origin, dynamics and conservation values', financed by the National Science Centre, Poland, following the decision DEC-2013/11/B/NZ9/00793.

Author contributions Conceptualization: AB, PC, PW; Methodology: AB, PW, JP; Phytosociological surveys: PW, JZ; Dendrochronological sampling: AB, MK, SH; Site conditions assessment: IMP; Tree ring measurements: SH; Data management and preliminary analyses: AB, PW, JZ; GIS and illustrative material: BO; Statistics: JP; Writing — original draft preparation: AB, KK; Writing — review and editing: AB, KK, PC, IMP; Funding acquisition: AB, PC; coordination and logistics in the Ukrainian part of the investigation: MK.

\section{Compliance with ethical standards}

Conflict of interest The authors declare no competing interests.

Consent to participate and publish There was a full consent of all authors to participate; all authors accepted the revised draft and gave consent to the corresponding author to submit it for publishing. 
Open Access This article is licensed under a Creative Commons Attribution 4.0 International License, which permits use, sharing, adaptation, distribution and reproduction in any medium or format, as long as you give appropriate credit to the original author(s) and the source, provide a link to the Creative Commons licence, and indicate if changes were made. The images or other third party material in this article are included in the article's Creative Commons licence, unless indicated otherwise in a credit line to the material. If material is not included in the article's Creative Commons licence and your intended use is not permitted by statutory regulation or exceeds the permitted use, you will need to obtain permission directly from the copyright holder. To view a copy of this licence, visit http://creativecommons.org/licenses/by/4.0/.

\section{References}

Affek A (2015) Spatially explicit changes in land ownership through 3 socio-political systems: A case study from southeast Poland. Geogr Polon 88:519-530. https://doi.org/10.7163/GPol.0032

Bergmeier E, Petermann J, Schröder E (2010) Geobotanical survey of wood-pasture habitats in Europe: diversity, threats and conservation. Biodivers Conserv 19:2995-3014. https://doi.org/10.1007/s1053 $1-010-9872-3$

Bobiec A (1998) The mosaic diversity of field layer vegetation in the natural and exploited forests of Białowieża. Plant Ecol 136:175-187. https://doi.org/10.1023/A:1009736823553

Bobiec A, Reif A, Öllerer K (2018) Seeing the oakscape beyond the forest: a landscape approach to the oak regeneration in Europe. Landsc Ecol 33:513-528. https://doi.org/10.1007/s10980-018-0619-y

Bobiec A, Podlaski R, Ortyl B, Korol M, Havryliuk S, Öllerer K, Ziobro J, Pilch K, Dychkevych V, Dudek T, Mázsa K, Varga A, Angelstam P (2019) Top-down segregated policies undermine the maintenance of traditional wooded landscapes: evidence from oaks at the European Union's eastern border. Lands Urban Plan 189:247-259. https://doi.org/10.1016/j.landurbplan.2019.04.026

Bonn S (2004) Dispersal of plants in the Central European landscape. Dispersal processes and assessment of dispersal potential exemplified for endozoochory. PhD Thesis, University of Regensburg

Braun-Blanquet J, Pavillard J (1925) Vocabulaire de sociologie végétale, 2nd edn. Roumégous et Déhan, Montpellier

Bruun HH, Fritzbøger B (2002) The past impact of livestock husbandry on dispersal of plant seeds in the landscape of Denmark. Ambio 31:425-431. https://doi.org/10.1579/0044-7447-31.5.425

Burst M, Chauchard S, Dupouey J-L, Amiaud B (2017) Interactive effects of land-use change and distance-to-edge on the distribution of species in plant communities at the forest-grassland interface. J Veg Sci 28:515-526. https://doi.org/10.1111/jvs.12501

Burst M, Chaucharda S, Dambrinec E, Dupoueya J-L, Amiaud B (2020) Distribution of soil properties along forest-grassland interfaces: Influence of permanent environmental factors or land-use aftereffects? Agric Ecosys Environ 289:106739. https://doi.org/10.1016/j.agee.2019.106739

Chabrerie O, Jamoneau A, Gallet-Moron E, Decocq G (2013) Maturation of forest edges is constrained by neighbouring agricultural landmanagement. J Veg Sci 24:58-69. https://doi.org/10.11 11/j.1654-1103.2012.01449.x

European Commission (2013) Interpretation manual of European Union habitats. DG Environment, Brussels, Belgium. http://ec.europa.eu/environment/nature/legislation/habitatsdirective/docs/Int_ Manual_EU28.pdf

Couvreur M, Vandenberghe B, Verheyen K, Hermy M (2004) An experimental assessment of seed adhesivity on animal furs. Seed Sci Res 14:147-159. https://doi.org/10.1079/SSR2004164

Diamond J (1986) Overview: laboratory experiments field experiments and natural experiments. In: Diamond JM, Case TJ (eds) Community Ecology. Harper \& Row, New York, pp 3-22

Dzwonko Z, Gawroński S (1994) The role of woodland fragments, soil types, and dominant species in secondary succession on the Western Carpathian foothills. Vegetatio 111:149-160. https://doi. org/10.1007/BF00040334

Ellenberg H, Weber HE, Düll R, Wirth V, Werner W, Paulißen D (1992) Zeigerwerte von Pflanzen in Mitteleuropa. Scripta Geobotanica 18, 2nd Ed

Faliński JB (1986) Vegetation dynamics in temperate lowland primeval forests: Ecological Studies in Białowieża Forest. Geobotany 8, Dordrecht - Lancaster

Fischer J, Hartel T, Kuemmerle T (2012) Conservation policy in traditional farming landscapes. Cons Lett 5:167-175. https://doi.org/10.1111/j.1755-263X.2012.00227.x

Froment A, Tanghe M (1967) Répercussion des formes anciennes d'agriculture sur les sols et la composition floristique. Bull Soc Roy Bot Belg, tome 100, série B: 335-352. 
Herlin IS (2001) How can an understanding of dispersal processes for woody species contribute to the establishment and management of hedgerows? In: Barr C, Petit S (eds) Hedgerows of the world their ecological functions in different landscapes. Int Assoc Landscape Ecol, UK Chapter, pp 147-156

Hermy M, Honnay H, Firbank L, Grashof-Bokdam C, Lawesson JE (1999) An ecological comparison between ancient and other plant species of Europe, and the implications for forest conservation. Biol Conserv 91:9-22. https://doi.org/10.1016/S0006-3207(99)00045-2

Hill MO, Gauch HG (1980) Detrended correspondence analysis: an improved ordination technique. Vegetatio 42:47-58

Jakubowska-Gabara J (1996) Decline of Potentillo albae-Quercetum Libb. 1933 phytocoenoses in Poland. Vegetatio 124:45-59. https://doi.org/10.1007/BF00045143

Kozłowska A (2000) The forest communities in the Przemyśl Foothills, south-east Poland. Fragm Flor et Geobot 45(1-2):345-372. http://maxbot.botany.pl/cgi-bin/pubs/data/article_pdf?id=696

Marage D, Rameau JC, Garraud L (2006) Soil seed banks and vegetation succession in the Southern Alps: effects of historical and ecological factors. Can J Bot 84:99-111. https://doi.org/10.1139/ B05-142

Matuszkiewicz JM (2008) Potencjalna roślinność naturalna Polski. IGiPZ PAN, Warszawa

Munteanu C, Kuemmerle T, Boltiziar M, Butsic V, Gimmi U, Halada L, Kaim D, Kiraly G, KonkolyGyuro E, Kozak J, Lieskovsky J, Mojses M, Muller D, Ostafin K, Ostapowicz K, Shandra O, Stych P, Walker S, Radeloff VC (2014) Forest and agricultural land change in the Carpathian region-A meta-analysis of long-term patterns and drivers of change. Land Use Pol 38:685-697. https://doi. org/10.1016/j.landusepol.2014.01.012

Newton AC (2007) Forest ecology and conservation. Oxford University Press, Oxford, A handbook of techniques

Öllerer K (2014) The ground vegetation management of wood-pastures in Romania - Insights in the past for conservation management in the future. Appl Ecol Env Res 12:549-562. https://doi.org/https:// doi.org/10.15666/aeer/1202_549562.

Öllerer K, Varga A, Kirby K, Demeter L, Biró M, Bölöni J, Molnár Z (2019) Beyond the obvious impact of domestic livestock grazing on temperate forest vegetation - A global review. Biol Conserv 237:209-219. https://doi.org/10.1016/j.biocon.2019.07.007

Ozinga WA, Hennekens SM, Schamin JHJ, Beldcer RM, Prinzing A, Bonn S, Poschlod P, Tackenberg O, Thompson K, Bakker JP, van Groenendael JM (2005) Assessing the relative importance of dispersal in plant communities using an ecoinformatics approach. Folia Geobot 40:53-67 https://link. springer.com/content/pdf/10.1007\%2FBF02803044.pdf

Peringer A, Schulze KA, Stupariu I, Stupariu MS, Rosenthal G, Buttler A, Gillet F (2016) Multi-scale feedbacks between tree regeneration traits and herbivore behavior explain the structure of pasturewoodland mosaics. Land Ecol 31:913-927. https://doi.org/10.1007/s10980-015-0308-z

Peterken GF (1984) Game M (1984) Historical factors affecting the number and the distribution of vascular plant species in the woodlands of central Lincolnshire. J Ecol 72:155-182. https://doi. org/10.2307/2260011

Plieninger T, Hartel T, Martín-Lopez B, Beaufoy G, Bergmeier E, Kirby K, Montero MJ, Moreno G, Oteros-Rozas E, Van Uytvanck J (2015) Wood-pastures of Europe: Geographic coverage, socialecological values, conservation management, and policy. Biol Conserv 190:70-79. https://doi. org/10.1016/j.biocon.2015.05.014

Poschlod P, Bonn S (1998) Changing dispersal processes in the central European landscape since the last ice age: an explanation for the actual decrease of plant species richness in different habitats? Acta Botanica Nederland 47:27-44. http://natuurtijdschriften.nl/record/541120

Rackham O (1980) Ancient woodland, its history, vegetation and uses in England. Edward Arnold, London

Ries L, Sisk T (2004) A predictive model of edge effects. Ecology 85(11):2917-2926. https://doi. org/10.1890/03-8021

Rinn F (2003) TSAP-Win ${ }^{\mathrm{TM}}$ Time Series Analysis and presentation for dendrochronology and related applications version 0.53 for Microsoft Windows 98, 2000, XP. Rinntech, Heilderberg

Roleček J (2005) Vegetation types of dry-mesic oak forests in Slovakia. Preslia 77:241-261

Rotherham ID (ed) (2013) Trees, forested landscapes and grazing animals: a european perspective on woodlands and grazed treescapes. Routledge, Abingdon Oxon

Rozas V (2003) Tree age estimates in Fagus sylvatica and Quercus robur: Testing previous and improved methods. Plant Ecol 167:193-212. https://doi.org/10.1023/A:1023969822044 
Samojlik T, Fedotova A, Kuijper DPJ (2016) Transition from traditional to modern forest management shaped the spatial extent of cattle pasturing in Białowieża Primeval Forest in the nineteenth and twentieth centuries. Ambio 45:904-918. https://doi.org/10.1007/s13280-016-0795-4

Sayer J, Sunderland T, Ghazoul J, Pfund J-L, Sheil D, Meijaard E, Venter M, Boedhihartono AK, Day M, Garcia C, van Oosten C, Buck LE (2013) Ten principles for a landscape approach to reconciling agriculture, conservation, and other competing land uses. Proc Natl Acad Sci USA 110, 83498356. https://www.pnas.org/content/pnas/110/21/8349.full.pdf

Szafer W (1953) Stratygrafia plejstocenu w Polsce na podstawie florystycznej (Pleistocene stratigraphy of Poland from the floristical point of view). Rocz Pol Tow Geol 22:1-99

Timár G, Molnár G, Székely B, Biszak S, Varga J, Jankó A (2006) Digitized maps of the Habsburg Empire - The map sheets of the second military survey and their georeferenced version Arcanum, Budapest

Van den Wollenberg AL (1977) Redundancy analysis. An alternative for canonical correlation analysis. Psychometrika 42(2):207-219

Varga A, Zs M, Biró M, Demeter L, Gellény K, Miókovics E, Molnár Á, Molnár K, Ujházy N, Ulicsni V, Babai B (2016) Changing year-round habitat use of extensively grazing cattle, sheep and pigs in East-Central Europe between 1940 and 2014: consequences for conservation and policy. Agric Ecosyst Environ 234:142-153. https://doi.org/10.1016/j.agee.2016.05.018

Vera FWM (2000) Grazing ecology and forest history. CABI Publishing, Wallingford

Verheyen K, Bossuyt B, Honnay O, Hermy M (2003) Herbaceous plant community structure of ancient and recent forests in two contrasting forest types. Basic Appl Ecol 4:537-546. https://doi. org/10.1078/1439-1791-00210

Wang B, Shi W, Miao Z (2015) Confidence analysis of standard deviational ellipse and its extension into higher dimensional euclidean space. PLoS ONE. https://doi.org/10.1371/journal.pone.0118537

Wulf M (2003) Preference of plant species for woodlands with differing habitat continuities. Flora 198:440460. https://doi.org/10.1078/0367-2530-00118

Ziobro J, Koziarz M, Havrylyuk S, Korol M, Ortyl B, Wolański P, Bobiec A (2016) Spring grass burning: an alleged driver of successful oak regeneration in Sub-Carpathian marginal woods. A case study. Prace Geograficzne 146:67-88. https://doi.org/10.4467/20833113PG.16.018.5548

Publisher's Note Springer Nature remains neutral with regard to jurisdictional claims in published maps and institutional affiliations.

\section{Authors and Affiliations}

\section{Paweł Wolański ${ }^{1}$ Andrzej Bobiec ${ }^{2}$ (D) - Bernadetta Ortyl ${ }^{2} \cdot$ Iwona Makuch-Pietraś $^{2}$. Paweł Czarnota $^{3}$. Jan Ziobro ${ }^{4} \cdot$ Mykola Korol $^{5}$. Serhii Havryliuk ${ }^{5}$. Jakub Paderewski ${ }^{6}$. Keith Kirby ${ }^{7}$}

Paweł Wolański

wolanski@ur.edu.pl

Bernadetta Ortyl

zawadzka@ur.edu.pl

Iwona Makuch-Pietraś

makuchiw@ur.edu.pl

Paweł Czarnota

pawczarnota@poczta.onet.pl

Jan Ziobro

j.s.ziobro@gmail.com

Mykola Korol

nikkorol@ukr.net

Serhii Havryliuk

serhiy_havrylyuk@nltu.edu.ua

Jakub Paderewski

jakub_paderewski@sggw.pl 
Keith Kirby

keith.kirby@bnc.oxon.org

1 Department of Agroecology, University of Rzeszów, Institute of Agricultural Sciences, Land Management and Environmental Protection, Rzeszów 35-601, Poland

2 Department of Nature Conservation and Landscape Ecology, University of Rzeszów, Institute of Agricultural Sciences, Land Management and Environmental Protection, Rzeszów 35-601, Poland

3 Department of Ecology and Environmental Protection, University of Rzeszów, Institute of Agricultural Sciences, Land Management and Environmental Protection, 35-601, Rzeszów, Poland

4 University of Rzeszów, Rzeszów, Poland

5 Ukrainian National Forestry University, Forestry and Park Gardening, Lviv 79057, Ukraine

6 Department of Experimental Design and Bioinformatics, Warsaw University of Life Science, 02-787 Warsaw, Poland

7 Department of Plant Sciences, University of Oxford, Oxford OX1 3RBL, UK 